\title{
Isolation of Natural Acid Base Indicator from the Flower Extract of Sarca Asoca, Abelmoschus Esulentus, Hibisucs Cannabinus And Hibiscus Rosa Sinensis
}

\section{Deepali Mourya ${ }^{1}$,Sushrut Maner $^{1}$, Mandar Lele ${ }^{2}$}

'Student Abhinav Jyan Mandir College of Arts Science and Commerce Karjat, Aamrai, Karjat, Maharashtra, India

${ }^{2}$ Assistant professor of Abhinav Jyan Mandir College of Arts Science and Commerce Karjat, Aamrai, Karjat, Maharashtra, India

\section{Article Info}

Volume 8, Issue 5

Page Number : 132-134

\section{Publication Issue}

September-October-2021

\section{Article History}

Accepted : 15 Sep 2021

Published : 23 Sep 2021

\begin{abstract}
Objectives :- The objective of this work is to use more plant indicators than chemical based indicators.

Saraca asoca is a species of family Fabaceae and Abelmoschus esculentus and Hibiscus cannabinus is a species of family Malvaceae [1]. Indicator are very special chemicals, they change colour of the solution with change in $\mathrm{pH}$ by adding acid or alkali. In the present work acid base titration has been performed by using natural indicators. The natural indicator is prepared from the most commonly occurring flower Hibiscus cannabinus, Abelmoschus esculentus Saraca asoca and Hibiscus Rosa sinensis. Aqueous and methanolic extract of flower were used as natural indicator. One acid one base were selected for acid base titration. Vinegar is used as acid and caustic soda is used as base. The results obtained by the natural indicator are almost similar to the result given by the synthetic indicators. Thus, natural indicator from flowers can be used for acid base titration [2]. Using aqueous extract of flower as indicator is more economical and with the same accuracy of result as that given by synthetic indicators.
\end{abstract}

Keywords :- Indicator, synthetic indicators, natural indicators, acid base titration

\section{INTRODUCTION}

Saraca asoca is a plant belonging to the legume family [3]. The Ashoka is a rainforest tree it's original distribution was in the central areas of Deccan plateau, as well as the middle section of western ghats in western coastal zone of the India subcontinent. The
Ashoka is praised for its beautiful foliage and fragrant flowers. It is a handsome, small, erect evergreen tree, with deep green leaves growing in dense clusters. Flowers are bright orange-yellow in colour turning red before wilting. It has been traditionally used in India Ayurveda as a uterine tonic and has been indicated in menstrual irregularities ESP in DUB. 
Ashoka happen to be a uterine stimulant and increase uterine contractions. It also stimulates the ovarian tissue. The bark of saraca is rich in hematoxylin, tannins, ketosterols, catechins, glycosides, etc.

Abelmoschus esculentus is annual growing to 1 meter it is hardly to zone 8 and frost tender. The species is hermaphrodite and is pollinated by bees. They can be used fresh or dried, they are commonly used as a thickening for soups, stews, and sauces. The fruits are also a fair source of iron and calcium. The fresh fruits contain 740 iu vitamin A the roasted seed is a coffee substitute. The seed contain up to $22 \%$ of edible oil. The leaves, flower buds, flowers are calyces can be eaten cooked as greens. It is also used as medicine.

Hibiscus cannabinus is an annual growing to 1.8 meter at a fast rate. It is hardly to zone 10 and is frost tender. The species is hermaphrodite and is pollinated by insect. The plant is self-fertile. The leaves have an acidic flavor. Seed roasted or ground into a flour and made into a kind of cake. Roots are edible but very fibrous. An edible oil is obtained from the seed. The juice of the flower mixed with sugar and black pepper is used in the treatment of biliousness with acidity, they are added to the diet in order to promote weight increase. An infusion of the leaves is used in the treatment of coughs.

The un-dissociated molecules of phenolphthalein are colorless while $\mathrm{pH}$ ions are pink in color. In the presence of an acid in the ionization of $\mathrm{HpH}$ is practically negligible as the equilibrium shifts to left hand side due to high concentration of $\mathrm{H}+$ ions. Thus, the solution would remain colorless on addition of alkali, hydrogen ions are removed by $\mathrm{OH}$ - ions. In the form of water molecules and the equilibrium shifts to right hand side. Thus, the concentration of $\mathrm{pH}$ - ions increase in solution and they impart pink color to the solution. The simple Ostwald theory of color of indicator has been revised, plant pigment general are termed flavonoids [4]. These include flavone, flavono, isoflavones, anthocyanins, anthocyanidin, etc. Anthocyanins occur as glycosies and their glycones i.e. free pigment are anthocyanidin. The color of flower due to the presence of anthocyanins.

The various shades of color exhibited by all flower are due to a very small number of different compounds contain the same carbon skeleton and differed only in nature of the substituent groups. Ore of these naturally occurring plant pigment are anthocyanins. These are water soluble and generally occur in the aqueous cell sap and responsible for the large variety of colors in flowers.

\section{Experimental}

Identification and collection of Saraca asoca, Abelmoschus esculentus, Hibiscus cannabinus and Hibiscus Rosa sinensis.

Flower were collected during spring season. Flower was collected for the purpose of study of natural indicator. It is available throughout the year. Fresh petals were collected in the month of June and August because it is the blooming season of plants. Natural indicator was isolated from the flowers. Several plants pigments like anthocyanins, flavonoids occur in petals of these flowers which acts like natural indicator. Flowers were cleaned by distilled water and petals of these flowers were kept in water for overnight. The next morning flowers smashed in the water to obtain the solution of this flowers. After that filter the solution. Clear solution should be obtained for indicator. The resulted aqueous extract was used as natural indicators for acid base titration. The extract was kept closed container and stored away from direct sunlight. By following the similar process for Abelmoschus esculentus Hibiscus Rosa sinensis and Hibiscus cannabinus extract of petals was prepared filtered and used as natural Saraca asoca, Abelmoschus esculentus, Hibiscus cannabinu and Hibiscus Rosa sinensis indicator. Reagents and 
volumetric solutions were prepared as per standard. The experimental work was carried out by using the same set of extract and the reagent were not calibrated. The titration was performed using five drops of natural indicator.

\section{RESULTS AND DISCUSSION}

The flower was screened for its use as an indicator in acid base titration and the results were compared with the results obtained by standard indicator.

\begin{tabular}{|l|l|l|}
\hline Flower Indicator & In acid & In base \\
\hline Saraca asoca & Reddish pink & Grey \\
\hline Abelmoschus & Light pink & Green \\
\hline Hibiscus cannabinus & Pink & Grey \\
\hline Hibiscus Rosa sinensis & Orange & Grey \\
\hline
\end{tabular}

The color changed from reddish-pink to grey in case of aqueous floral extract not Saraca asoca as natural indicator and the color change from light pink to green in the case of aqueous floral extract of Abelmoschus esculentus as natural indicator and the color change from pink to grey in the case of Hibiscus cannabinus as natural indicator, color change from orange to grey can in the case of in Hibiscus Rosa sinensis.

\section{IV.CONCLUSION}

The synthetic indicators are very hazardous to health and cause pollution therefore to solve this problem floral extract has been selected as a source of Indicator of acid base titration. The accuracy of results has been judged by performing a variety of acid base titration. The results were obtained by Saraca asoca, Abelmoschus esculentus Hibiscus Rosa sinensis and Hibiscus cannabinus. The standard deviation for synthetic indicators, and aqueous extract of natural indicator shows very less variation in the results. Statistically also the use of natural indicator in acid base titration is proved. Hence aqueous extract can be used with cent percent reliability and accuracy for acid base titration. Thus, use of natural indicator in acid base titration is more beneficial because of their economy, easy to prepare, easy availability, pollution free, inert and accurate results.

\section{REFERENCES}

[1]. CHECK LIST OF FLOWERING PLANTS IN TAPI DISTRICT, GUJARAT, INDIA Sandip B. Gamit1 ,Rupesh R. Maurya , Umerfaruq M. Qureshimatva and Hitesh A. Solanki International Journal of Advanced Research (2015), Volume 3, Issue 10, $1104-1123$

[2]. FLOWER EXTRACT AS AN IMPROVISED INDICATOR IN ACID - BASE TITRATION Mahadi D. Garba and S. Abubakar Chemsearch Journal 3(1): 17 - 18 June, 2012 Publication of Chemical Society of Nigeria, Kano Chapter

[3]. Reproductive biology and breeding system of Saraca asoca (Roxb.) De Wilde: a vulnerable medicinal plant G. R. Smitha* and V. Thondaiman SpringerPlus (2016) 5:2025 DOI 10.1186/s40064-016-3709-9

[4]. Stabilizing and Modulating Color by Copigmentation: Insights from Theory and Experiment .Patrick trouills DOI: 10.1021/acs.chemrev.5b00507 Chem. Rev. 2016, 116, 4937-4982

\section{Cite this article as :}

Deepali Mourya, Sushrut Maner, Mandar Lele, "Isolation of Natural Acid Base Indicator from the Flower Extract of Sarca Asoca, Abelmoschus Esulentus, Hibisucs Cannabinus And Hibiscus Rosa Sinensis", International Journal of Scientific Research in Science and Technology (IJSRST), Online ISSN : 2395-602X, Print ISSN : 2395-6011, Volume 8 Issue 5, pp. 132-134, September-October 2021. Available at doi : : https://doi.org/10.32628/IJSRST218528

Journal URL : https://ijsrst.com/IJSRST218528 